\title{
Retraction Note: Characteristics of rainfall pattern change in mountainous area based on dynamic adaptive and sustainable development of agricultural tourism
}

Xue $\mathrm{Li}^{1}$

Published online: 29 November 2021

(c) Saudi Society for Geosciences 2021

Retraction Note:Arabian Journal of Geosciences (2021) 14: 1686

https://doi.org/10.1007/s12517-021-08024-Z

The Editor-in-Chief and the Publisher have retracted this article because the content of this article is nonsensical. The peer review process was not carried out in accordance with the Publisher's peer review policy. The author has not responded to correspondence regarding this retraction.

The original article can be found online at https://doi.org/10.1007/ s12517-021-08024-z.

Xue Li

zbvclixue2021@126.com

1 Zibo Vocational Institute, Zibo, Shandong, China 